\title{
XXV. Description of a new safety-piston for Papin's digester, with the application of it to the boilers of steam-engines, and also of an apparatus for regulating the heat of furnaces
}

\section{A.N. Edelcrantz}

To cite this article: A.N. Edelcrantz (1803) XXV. Description of a new safety-piston for Papin's digester, with the application of it to the boilers of steam-engines, and also of an apparatus for regulating the heat of furnaces, Philosophical Magazine Series 1, 17:66, 162-164, DOI: $10.1080 / 14786440308676390$

To link to this article: http://dx.doi.org/10.1080/14786440308676390

\section{Published online: 18 May 2009.}

Submit your article to this journal ¿

\section{Џll Article views: 2}

Q View related articles ¿ 
seren gros and three grains of salt, which exhibited the same phenomena as muriate of barytes.

It appears to result from these experiments, that in evaporating a mixture of a solution of muriate of barytes and phosphoric acid, towards the end of the process, when the saline mass already formed is capable of bearing a greater degree of heat than that of boiling water, some muriate of barytes is decomposed, which can combine with a part of the free phosphoric acid.

But that no proper decomposition of the muriate of Barytes takes place by the action of the phosphoric acid, seems to be proved by the large quantity of undecomposed salt and pure phosphoric acid which was again obtained.

I shall abstain from any further inquiry why Morveau and Gren obtained a precipitate by coinbining this salt with phosphorit acid: but I think I can on good grounds conclude, that ncither of these chemists made their experiments with pure phosphoric acid.

XXV. Description of a New Safety-Piston for Papin's Digester, with the Application of it to the Boilers of steam-Engines, and also of an Apparatus for regulating the Hent of Fumaces. By A. N. EswlchanTz, Knight of the Su'edish Order of the Polur Star, and Memler of sectral Academies and Lcarned Societies.

$$
\text { SII, }
$$$$
\text { To Mr. Tilloch. }
$$

Agreanatr to your desire, I have sent you the description of a safety-piston which I hav employed in Papin's digesters; the use of which I have endeavoured to render mole exact, safer, and more convenient $\%$. This small apparatus, attached to the cuver of the digester, consists of a brass cylinder $a b$, fig. 2 . (Hate III.) in which a piston of the same metal, $c d$, moves with very little friction, in order that it may descend by its own weight atter it has been raised up, without however permitting the vapour to pass between it and the cylinder. "The lower part of the cylin(ier communicates with the digester, and is covered by a sinall sphere, $s, s$, perforated with holes, to prevent the matters in a state of ebullition from entering the in-

The description of my piston may be seen in the Fournal de 7bysigue, rol. lvi. p. 147. But since tha: time I have made some change in its construction. 


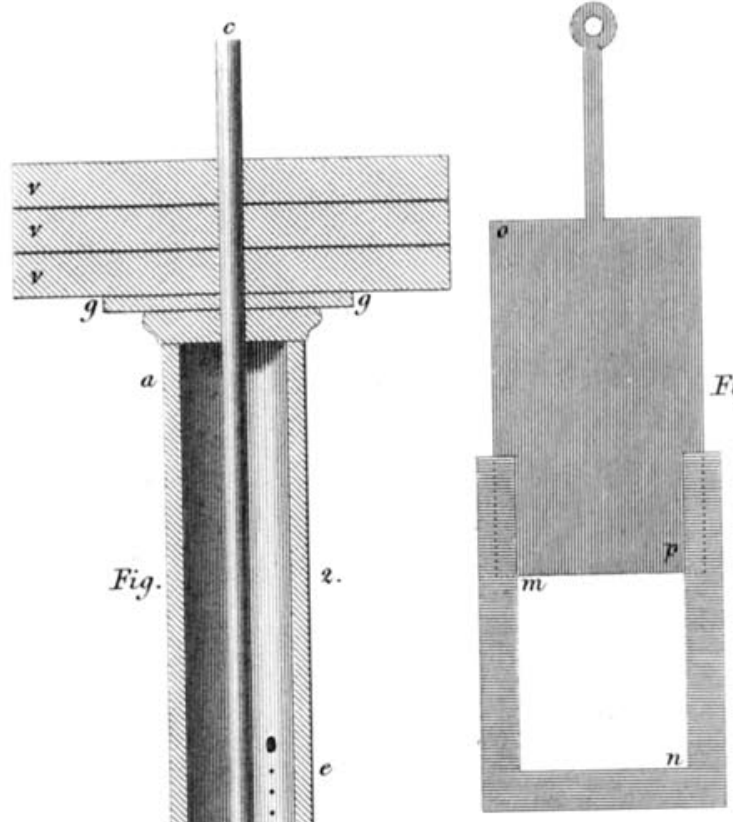

Fig. 3.

Fig.1.

Fig. 4 .

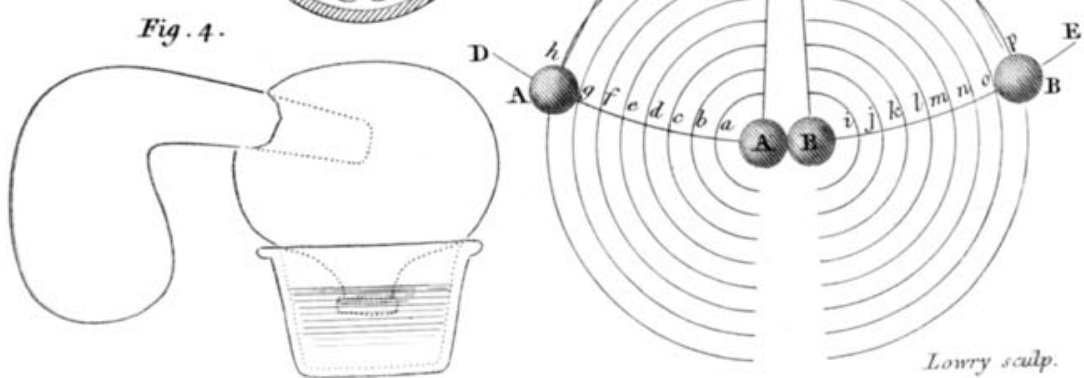


side of it, but allowing the vapour to pass. The upper part $(a)$ is closed by a small cover screwed on to it, and perforated with a hole through which the piston-rod passes easily. This cover serves the double purpose of guiding the rod, and preventing it from being blown oul: The piston-rod is furnished with a shoulder; $g, g$, which serves to support different weights, $v v v$, which can be changed at plcasure. In the side of the cylinder there are holes, $e, e$; as sinall as possible, placed above each other at the distance of about a line; but this distance, as well as the number of them, is a matter of indifference.

To give an idea of the effect of this small apparatus, let us suppose the piston lowered, and loaded with any weight, and that a fire is kinclled under the boiler. When the vapour has acquired sulficient elasticity to raise the weights, the piston will ascend, and, having passed the first hole, some vapour will escape. If this aperture be of sufficient size for the passage of the quantity of vapour continually produced, the piston will remain there stationary, and in a state of oscillation; if not; it will ascend above the second, third, \&c. hole, and, if the intensity of the fire is sufficiently strong, above the last, which must be made larger; that, by giving the proper means of escape to the vapour; all accidents may be prevented. It is here evident, that though the greater or less elevation of the piston, as well as the number of the holes open, depends on the variations and different intensities of the fire; thesc variations, horvever, have no inflience on the interior heat, and the elasticity of the vapour contained in the digester, since their force is always proportioncd to the weight with which the piston is loaded, and which is constant. This safety-piston seems likely to afford, for delicate experiments, greater exactness than the usual saficty-valves, with or without levers charged with weights, hitherto employed. For, in the whole course of the space which the cylindric piston passes over in ascending, the state of the elasticity of the vapour is the same; whereas, when the conical valve in common ase is once raised up, nothing indicates whether, or how much, the present state of the vapour surpasses the first effort it. made to open a passage. Besides, hise diameter of the piston being once lnown, the force of the vapour requisite for each experiment can be easily regulated and determined. If we suppose, for example, that the lower surface of the piston is $\frac{1}{16}$ th of a square inch, each ounce of weight on the shoulder, $g$, will be equivalent to the pressure of a pound on each square inch of surface, and so on in proportion. L 2 


\section{Description of Mr. Atthur Woolf's Steam-Ialve.}

As this pressure then remains constant, the experiment will be more determinate, and consequently more comparative.

The application of this piston to the boilers of steam engines needs no further explanation, except that, in this case, the diameter of the piston must be considerably inereased. It secms here to ofier the same advantage of greater uniformity in the force of the steam, especially if the motion of the piston be employed to regulate the fire of the furnace, and to prevent the useless dispersion of the rapour, by preventing anl excess of intensity in the fire: Fior this purpose, the following apparatus may be used. Let $m, n, f i g .3$. be the aperture of the conduit for the current of air which maintains the combustion of the fuel, gnd $o, p, a$ rcgister; which, by rising or falling, opens or shuts that conduit: If the motion of the safety piston be combined by ant means with the register, in such a manner that, when the former ascends, the latter descends, so that when the piston is at its greatest elevation the register shall be entirely shut; it is evident, that, since the heat produced depends on the access of the air, the elasticity of the vapour being determined by the weight of the piston, will not only remain within the bounds prescribed for it, but will regulate itself, by preventing more air from entering into the fumace than is necessary to maintain its force.

I do not know what obstacles may occur in the application of this apparatus on a large scale; but it seems to promise a greater saving of fiel, since, instead of throwing out to no purpose a staperabundant quantity of vapour, it will prevent its production, without expending any considerable part of the force of the machine for that purpose.

\section{Description of $M r$. Anthur Woolf's Steum-Falue.}

In our last we had before our readers an account of Mr. Woolt's newly inrented boiler, in which we inentioned that, besides cmploying saficty-ralres, he had introduced $\mathbf{x}$ valve of a new construction to regulate the quantity and power of the steam passing from the boiler. We shall now lay before them a description of this ingenious contrivance.

A (Plate IV.) is a part of the main cyliniter of one of Mr. Woolf"s boilers; B B the neck or outlet for the steam, surmounted by the steam-box $\mathrm{C}$, which is joined to the neck 